\title{
The Commission's internal conditions for social re-regulation: Market efficiency and wider social goals in setting the rules for financial services in Europe
}

Miriam Hartlapp, Social Science Research Centre Berlin and University of Bremen

Christian Rauh, Social Science Research Centre Berlin

\begin{abstract}
The European Union is often considered as a prime example of a liberal regulatory state. We argue, however, that being limited to the regulatory policy does not prevent the European Commission from pursuing political aims going beyond market efficiency. We draw up two ideal-type perspectives of market regulation being either efficiency or equality enhancing - that differ systematically in terms of rationale, degree of intervention, patterns of stakeholder access and conflict within the regulator. We trace these aspects in three financial services initiatives on the registration and supervision of reinsurers, equal treatment in financial services and the regulation of consumer credit. Our analyses suggest that there is scope for equality-enhancing re-regulation when proactive agents proceed decidedly on the basis of social-treaty concerns and frame regulatory beneficiaries as market participants as well as when they seek the redistribution of rights instead of resources.
\end{abstract}

\section{JEL classification}

G28

\section{Keywords}

European Union; regulation; financial services; equality enhancement

\section{Acknowledgements}

The paper is part of a multi-annual, collaborative research project on 'Position Formation in the EU Commission' being carried out at the Social Science Research Centre Berlin. Funding from the Volkswagen Foundation is gratefully acknowledged. More information on the project can be found at http://www.wzb.eu/en/research/civil-society-conflicts-and-democracy/positionformation-in-the-eu-commission. We are also indebted to our colleague Julia Metz for fruitful discussions. An earlier version of the paper was presented at the workshop entitled 'The Future of The Regulatory State: Adaptation, Transformation, or Demise?' held at the BI School of Management, Oslo (15-16 September 2011). We thank the participants and especially David Levi-Faur for helpful comments. 


\section{Introduction}

Limited possibilities for taxation and meagre budgets severely restrict the EU regarding the pursuit of wider social goals through governmental redistribution of existing resources. Rather than as a positive state, the EU has been characterized as the leading example of a liberal regulatory state that focuses mainly on the correction of various market failures (Majone, 1993, 1997). The fact that EU regulation emerged increasingly as a response to the privatization of utilities (Grande, 2011) has added to the view that the Union's first and foremost regulatory aim is the efficiency of the Single European Market.

However, the traditional welfare state at the national level has also partly relied on regulatory components (Mabbett, 2009; Leisering, 2011a) while the definition of the regulatory does not necessarily imply particular political goals (Levi-Faur, 2012: esp. 14-16). Influential authors have identified a European social policy, although being of the regulatory type (Leibfried, 2010; Falkner et al., 2005). Clearly, EU regulation covers increasingly broad social themes, including, for example, consumers, the environment and energy (Knill et al., 2003; Vogel, 2003; Coen et al., 2008). Moreover, the demand for European regulation with a more social face has increasingly been on the agenda since the failed referendums in 2005 and since the financial crisis that put the spotlight on the downsides of unfettered market forces. So while EU decision-making has a strong regulatory thrust, regulation is not automatically tied to the (political) ambition for liberalization, but may also be a vehicle for attaining distributive goals. Consequently, it is relevant to ask for the conditions under which EU market regulation pursues social goals that go beyond mere market efficiency.

We tackle this question with regard to the European Commission. The long-term perspective of its regulatory staff, its unique access to broad policy expertise and, especially, its formal monopoly of legislative initiative all provide the Commission with substantial influence over the contents of European regulation (Princen, 2009; Tsebelis et al., 2000). However, against the background of external constraints most notably the provisions of EU treaties, as well as political preferences in the Council of Ministers and the European Parliament - the Commission must keep up the appearance of impartiality and thus has reason to mask the outright pursuit of social goals. Following an ideal-type distinction between efficiency-enhancing and equality-enhancing regulation, we argue in Section 2 that the Commission's ambitions can nevertheless be identified if we take the systematic differences between the regulatory processes into account.

This claim is supported by comparing three short histories of drafting processes on financial services regulations presented in Section 3. Initially, the European financial services market could have been realized through liberalization and the simple application of the freedoms of movement enshrined in the EU treaties. However, especially since the publication of the EU Green Book on the financial services market in the late 1990s, European regulation of the sector abounds (Posner et al., 2010: 400). In shifting from the coverage of purely commercial activities to retail financial services for private consumers, 'the FSAP [Financial Service Action Plan] represented a change in EU strategy away from market opening measures towards common regulatory measures' (Quaglia, 2010: 1007). These efforts may only be a consequence of further market integration, but they still make financial services a promising policy area for studying regulatory capacities that go beyond market efficiency and the regulatory processes that push the Commission towards the pursuit of wider social concerns. We trace the theoretically developed characteristics with respect to three regulatory processes on financial intermediaries, equal treatment in service markets and consumer credit. 
The article generates two expectations regarding the conditions under which the European Commission places a more social European market on the legislative agenda. While its capacity remains limited to the regulatory section of the overall social policy spectrum, the Commission can and does proactively redistribute rights 1) where this is pushed by specific internal actors who are in turn able to draw on a decidedly social-treaty base and frame the societal beneficiaries as market participants, and 2) where rights rather than resources are at stake, typically to the benefit of diffuse stakeholder interests. Under these conditions, it becomes possible to propose equality-enhancing regulation that goes beyond the aim of more efficient competition.

\section{Conceptualizing regulation: Market efficiency and wider social equality}

This article seeks to contribute to the debate on whether and under which conditions Europe's markets can be embedded 'within a broader set of social and political rules and cultural understandings that make them work not only more efficiently but also more equitably, with greater security for market and nonmarket participants and in tune with a variety of other social purposes' (Caporaso et al., 2009: 579). Existing research on this question differs along two perspectives. Firstly, it focuses on the implications of EU decisions for national welfare-state models. EU integration's lack of social embeddedness is ascribed to the systemic features of supranational decision-making, which prevent the reproduction of welfare states at the supranational level (Scharpf, 1999, 2010). Our interest here is more circumscribed, focusing on the re-regulatory capacity of day-to-day policymaking in Brussels. In other words, we accept the premise that the EU is a regulatory state with very limited capabilities for redistributing resources directly and that its regulatory instruments are constrained by the nature and interests of the inter-institutional process. However, any European market regulation must start with a policy proposal by the Commission, which in turn defines the issues as well as the strategic preferences that govern inter-institutional negotiations (Princen, 2009; Tsebelis et al., 2000). So if Commission proposals are not a priori equality enhancing when adopted by the Commission, the chances are low that such a policy orientation will be produced later in the policy cycle. Focusing on Europe's central agenda-setter is thus crucial for understanding the scope for and the degree to which EU regulation can be embedded in a social dimension.

A second dividing line in the literature runs between arguments about the natural or spontaneous emergence of market embeddedness and contributions highlighting the necessity for political construction in the pursuit of distributive goals. The former perspective is often evoked in relation to ECJ rulings in the area of antidiscrimination policies or cross-border health care (Hervey et al., 2007; more critical Höpner et al., 2012), but here we are concerned with intentional political construction. We start from the premise that market embedding is not an autonomous process, rather depends on specific conditions linked to decisive regulatory actors such as the European Commission.

These decisions already highlight the fact that the Commission only occupies the middle section of a larger social policy continuum that spans from completely unfettered markets, on the one side, to an autocratic distribution of resources along social justice criteria, on the other. Strictly speaking, only a section somewhere in between these extremes is filled with regulatory policy where authoritarian intervention is based on rules stated in general terms. But also within this section, the regulator will explicitly or implicitly decide on 'who will be indulged and who deprived' (Lowi, 1964: 690-1). In this view, regulation makes a socially relevant difference (Braithwaite et al., 2007) and the narrow section should already provide crucial insights concerning the conditions under which a policy outcome will be situated more towards one or the other end of the entire social policy continuum. Even when we only look at regulatory means, the outcome can be markets of very 
different social quality. We start from a rough distinction between two ideal-type perspectives on the organization and purpose of markets as a mode of social interaction: they may be either seen to produce the optimal allocation of resources in the equilibrium of economic supply and demand or as a socially constructed mechanism that balances competing values and demands.

The classical perspective of welfare economics starts from the utility of individual actors in the marketplace. It assumes that the socially optimal allocation of resources is attained when no individual can be made better off without disadvantaging others. Such a Pareto-efficient outcome is reached through the equilibrium of supply and demand, which in turn can only be achieved in a perfectly competitive market where the individual market participants try to maximize their individual welfare (Stiglitz, 1986). But even from this perspective, some regulation is required to preserve the market (Weingast, 1995), for instance with respect to property rights or contract certainty. In practice, markets are hardly commensurate with a model of perfect competition, for example where information is asymmetrically distributed among the market participants (Akerlof, 1970). Thus, classical welfare economics considers market regulation to be warranted where markets fail, externalities accrue or other imperfections prevent optimal decisions on the part of individual market participants (see, e.g.,Majone, 1996: esp. 28-30). In this perspective, regulation is seen only as a second-best solution to the outcomes a fully competitive and undistorted market would produce.

A second perspective on market regulation criticizes this purely economic view from normative points of departure (see Prosser, 2006 or; McVea, 2005). Approaches in this vein argue that market efficiency is qualitatively different from other, equally legitimate purposes of social interaction, such as social justice. Here, regulation does not target perfect competition in markets, but rather aims to alter their very quality by changing the rules under which individual transactions will be carried out. Instead of guaranteeing the mere pursuit of individual welfare, regulation addresses misallocation from a moral point of view, and is thus seen as a 'balancing of competing values setting out the sort of society we wish to live in' (Prosser, 2006: 375). This is consistent with the distinction between economic and social regulation that has figured prominently in the US debate on regulatory market interventions (cf. Reagan, 1987: esp. ch. 2). In the context of the EU, this approach has also been described as 'market cushioning policies' (Sbragia et al., 2008: 133; Sbragia, 2000; similarly, 'market shaping' Quaglia, 2010; 'extended regulation' Leisering, 2011b: 6). While economic regulation aims at freeing competitive forces, social regulation is primarily motivated by problems that often cannot be solved by an increase in economic competition alone. Rather than targeting the individual pursuit of welfare, social regulation aims at protecting broader societal groups from systematic disadvantages they may encounter in competitive markets (Ramsay, 1995).

We argue that the two perspectives should result in different models of regulation. Of course, in practice regulators often simultaneously face demand to create efficient markets that minimise burdens on industry and to create societies that are more just, equal and socially cohesive - and thus differ from the outcomes produced by market forces alone. In practice, thus we expect to see various mixtures "of interconnected and interdependent social and economic values, and that the distinction [...] lies in the primacy of the values it is designed to advance and the purpose it is designed to achieve" (Windholz et al., 2013: 25), Yet, while analytical boundaries might be very fuzzy at times deriving ideal-types allows us to point out more specific empirical implications which ultimately lead us to a finergrained perspective on the European Commission's choices and options in embedding European markets in wider social concerns. The discussion so far yields the following two ideal types of regulation:

In the first perspective - termed 'efficiency enhancing' - regulation is perceived as necessary to increase the immediate functioning of markets by countering market 
failures or imperfections understood as non-optimal transactions. Regulation should be expected where markets face a lack of competition due to monopolies, negative externalities or informational asymmetries. The beneficiaries of regulation are individual market participants.

In the second perspective - termed 'equality enhancing' - market regulation is perceived as necessary to deliver broader societal goals and operates with a more long-term perspective on market gains. Such regulation is motivated by other goals than purely increasing competition. Structurally weaker parties in market transactions are the beneficiaries of regulation.

Most importantly, distinguishing these two ideal-types is at odds with the seminal perspective on the regulatory state, which is most often portrayed as the polar opposite of the positive (welfare) state (Majone, 1997: 149; Levi-Faur, 2012: 1215). In this account, the main function of the positive state is Keynesian macroeconomic stabilization and redistribution. Majone's regulatory state by contrast puts administrative and economic performance first - it is 'efficiency enhancing'. In between these extremes, the 'equality-enhancing' perspective we develop here implies that there is a socially and analytically relevant middle ground. And this middle ground should differ from both the liberal regulatory state and the positive state not only with respect to long-term outcomes 'but with regard to access, procedures and organization' (Leisering, 2011b: 258, original emphasis). However, what follows from Majone's original distinction for a 'state' model that sits in between, and that starts with a clear (re)distributive function operates through regulation only? We argue that if the goals of regulation differ, as the original distinction of the ideal types suggests, then also the process of rulemaking at the EU level should deviate from the typical regulatory state model in at least four respects.

First, in his seminal conceptualization of the regulatory state, Majone argues that redistributive consequences result from 'potential policy constraints rather than policy objectives' for regulators (Majone, 1997: 162). In this efficiency-enhancing world, policy-makers try to avoid costs for any market participant by striving for a solution that is beneficial to all. In contrast, the equality-enhancing perspective implies that actors will focus on the creation of benefits for particular market participants that may or may not imply costs for others - this is in line with taxing and redistribution under the positive state. Rather than a constraint, (re)distributive consequences should become the rationale of regulation in an equality-enhancing model.

Secondly, the envisaged structure of the regulatory interventions should differ. In an efficiency-enhancing world, and in line with the goal of individual choice, as many decisions as possible are delegated to the market participants themselves, so that 'indirect government' best describes the mode of regulatory production as well as the regulatory contents (Majone, 1997: 146-8). By contrast, the equalityenhancing perspective implies that markets produce skewed outcomes so that the regulators will take as many decisions as possible themselves and try to set conclusive rules for the issue in question.

Thirdly, the two ideal types should differ with respect to the underlying conflict dimension and the related integration of external stakeholders into the regulatory process. Especially in the EU multilevel system, stakeholder integration is best understood as support from allies. The positive state is typically associated with corporatist patterns structured around class conflict. Capital and labour are granted access at the level of organized interests (Cioffi, 2009: 244). Under such representational monopolies, access to the regulator is biased (Schmitter et al., 1979). Majone's regulatory state, by contrast, moves away from this central political dynamic and implies competition among single-issue interest groups. Following pluralist theory (Truman, 1951), regulators grant equal access to the different sides of the debate and act as neutral arbiters searching for the equilibrium solution. The 
influence of external stakeholders might be biased, but the bias should not result from prefixed access patterns, rather from competition between the interests. Under the equality-enhancing model, stakeholder access should cease to be neutral without, however, focusing only on the conflicts underlying the capitalistlabour divide. Where normative imbalances among pluralist contending interests are the starting point of regulation, regulators should grant privileged access for those groups whose interest they see specifically at stake. The equality-enhancing model is thus more consistent with the neo-pluralist view on interest-group integration (cf. Dunleavy et al., 1987).

Lastly, the two possible worlds of regulation should differ concerning the way actors within the Commission interact. As the EU's agenda-setter, the Commission is not a unitary actor when proposing regulation, rather different interests prevail. The position finally proposed is the outcome of a long internal process characterized by multiple and often conflictual interactions (Hartlapp et al., 2013). In the seminal conception of the regulatory state, governmental actors 'usually cast their arguments in the language of 'regulatory science' rather than in the more traditional language of interest or class policies' (Majone, 1997: 157). Arguments should focus on technically 'best' solutions, and actors should adhere to 'a problem-solving rather than a bargaining style of decision-making' (ibid: 162). By contrast, the equality-enhancing perspective emphasizes normative differences in the quality of markets and should thus be much more prone to political conflict and more fundamental political exchange among actors.

Table 1: Ideal-type models of regulation in between unfettered markets and the positive welfare state

\begin{tabular}{|c|c|c|c|c|}
\hline & $\begin{array}{l}\text { Unfettered } \\
\text { Markets }\end{array}$ & $\begin{array}{c}\text { Efficiency-enhancing } \\
\text { Regulation }\end{array}$ & $\begin{array}{c}\text { Equality-enhancing } \\
\text { Regulation }\end{array}$ & Positive State \\
\hline Rationale & Competition & Market failure & $\begin{array}{l}\text { Redistribution } \\
\text { of rights }\end{array}$ & $\begin{array}{l}\text { Redistribution } \\
\text { of resources }\end{array}$ \\
\hline Intervention & None & $\begin{array}{l}\text { Least intrusive } \\
\text { rule-making }\end{array}$ & $\begin{array}{l}\text { Encompassing and } \\
\text { conclusive } \\
\text { rule-making }\end{array}$ & $\begin{array}{c}\text { Taxing/Spendi } \\
\text { ng }\end{array}$ \\
\hline $\begin{array}{l}\text { Stakeholder } \\
\text { access }\end{array}$ & Irrelevant & $\begin{array}{l}\text { Pluralist: } \\
\text { Self-selection }\end{array}$ & $\begin{array}{c}\text { Neo-pluralist: } \\
\text { Privileged access }\end{array}$ & $\begin{array}{l}\text { Corporatist: } \\
\text { Class-based } \\
\text { representation }\end{array}$ \\
\hline $\begin{array}{l}\text { Conflict } \\
\text { structure }\end{array}$ & Price & Expertise driven & Norm driven & Party driven \\
\hline
\end{tabular}

Summarized in Table 1, we can now identify equality-enhancing regulation as a distinct option for rule-makers. It is located in between unfettered markets and the idealized positive welfare state and, more importantly, it distinguishes itself from the efficiency-enhancing regulation usually associated with the regulatory state not only in terms of policies proposed, but also with regard to the regulatory processes at work. On the basis of these procedural differences, we can analyse whether the European Commission actually pursues equality-enhancing regulation and what scope there is for the social embeddedness of Europe's internal market.

\section{Tracing equality-enhancing regulation in the European Commission}

The outcome we are interested in is the extent to which a policy is equality enhancing, whereas the market-failure perspective in the classical regulatory state model of the Commission serves as our baseline expectation. In other words, our empirical starting point is the Commission's regulatory output and, more specifically, the degree to which a Commission proposal deviates from the regulatory status quo in the name of efficiency or social equality.

In order to highlight how the regulatory processes leading to these outcomes differ systematically we selected three cases from a broader project that studies decision-making within the Commission on the basis of semi-structured interviews 
conducted in Brussels between 2006 and 2009 with involved Commission officials from different Directorates-General and hierarchical levels. ${ }^{1}$

Firstly, the proposed directive on financial intermediaries, by regulating registration and consumer rights, seeks to establish an efficient single market for insurers distributing financial products on their own account. Secondly, the proposed directive on equal treatment in the access to and supply of goods and services for men and women and for all persons irrespective of religion or belief, disability, age or sexual orientation addresses the disadvantages facing specific groups in financial markets, for example with respect to insurance contributions and benefits or the conditions for loans. And, thirdly, the final act seeks to protect vulnerable consumers by regulating creditor obligations concerning the advertisement, conclusion and termination of consumer credit agreements. Whereas the first proposal follows an efficiency-enhancing logic, the second two cases lean towards the equality-enhancing side. Tracing the three regulatory processes, we work our way through the four dimensions of the two ideal types derived above. While the very notion of ideal-types excludes the possibility of finding them empirically in pure form, we should find evidence that decision-making in the Commission deviates from the classical regulatory-state model by following the logic of distributing political benefits, neo-pluralist and intentionally skewed interest group access, as well as substantial internal conflict instead of efficiency-enhancing problem-solving.

\section{The models in practice: Drafting European regulations on financial services}

A first case that provides insights on the Commission's internal conditions for reregulation is the regulation of reinsurers and financial intermediaries as institutions that redistribute financial products on their own account - such as travel agencies or car dealers. ${ }^{2}$ Although a forerunner directive with a narrower scope as well as a non-binding recommendation already existed, the regulatory logic was one of interface management rather than common-market regulation. The size of national markets differed, with in some cases more than 50 percent of insurance being distributed via intermediaries (the figures are especially high in Belgium, the Netherlands, the UK and Ireland, but are low in Denmark). National rules varied 'with regard to the access and purchase of the activity, in particular with regard to financial capacities [and] professional relations' (COM109), de facto confining intermediaries to their national markets. Especially with respect to consumer interests, member states typically had national rules in place. Accordingly, commercial actors faced substantial uncertainty regarding which rules to apply in cross-border markets (Dassesse, 1997:108).

Commissioner Monti first announced the new regulation in February 1997 (AE, 1997a) and the proposal was adopted in 2000. For DG MARKT, the rationale was to boost the retail market in insurance for private individuals through further liberalization, much along the lines this had been achieved for the wholesale market of large industrial and commercial risks. To this end, one part of the proposed directive established a single registration system in the member state of origin which harmonized the recognition of insurance agents and brokers throughout Europe (a regulatory logic also applied to other directives, Quaglia, 2010: 1030) and went hand in hand with professional requirements and supervision through the country of origin. A drafting official summarized this rationale as follows: 'we did it, because it was worth for the industry and also to enforce the internal market. It was a very heavy case, where not a lot of work was

\footnotetext{
${ }^{1}$ In order to preserve interviewee anonymity, we refer to the interviews as 'COM1', 'COM2', etc.

2 Proposal for a Directive of the European Parliament and of the Council on insurance mediation (COM(2000)511).
} 
necessary from the internal market viewpoint' (COM109). The other group of provisions considered a necessary ingredient for making retail markets for intermediaries function efficiently was to strengthen the position of consumers by introducing information and disclosure rights as well as facilities for complaints: '[l]t will increase the choice of insurance products available to customers and help ensure they can trust the advice they are getting from intermediaries' (Commissioner Bolkestein, cited in: AE, 2002, likewise COM109). Clearly, in this case, consumer protection was not sought as a right per se, but to prevent the failure of a common market for financial mediation and thus qualifies as efficiency enhancing.

Different sources provide evidence that drafting did not take place behind closed doors and that external stakeholders were relevant in explaining both the choice of a binding instrument with a broad scope that included small intermediaries, as well as the other substantial provisions of the proposal (AE, 1997a, COM109). Following the efficiency-enhancing model, DG MARKT consulted broadly not only across several member states and the EP, but also across stakeholders from the financial services industry, notably the European Insurance Committee (EIC), the Association of European Cooperative Insurers (AECI), intermediaries such as the International Association of Insurance and Reinsurance Intermediaries (BIPAR) and customers represented by the European Bureau of Consumers' Unions (BEUC; COM109). These single-issue interest groups finally all found their positions represented in the proposal. The binding provisions clearly open the market for cross-country provision of services and thereby foster competition between professional insurance intermediaries more strongly than earlier, nonbinding recommendations. And they do so 'within a clear framework of common rule to protect the consumer' (BEUC Director Jim Murray, cited in AE, 1997a; similarly BIPAR in AE, 1997b).

Drafting inside the Commission stretched over a period of five to six years and different portfolios were involved (COM109). Although DG SANCO, especially, was reported to have argued for consumer interests to be reflected, the actors involved did not perceive the interaction as being conflictual and reported that all internal comment was taken on board (COM109). In combination with the obviously negligible interest at the political level for this rather technical directive, the process followed a problem-solving logic.

The second case is the promotion of equality of opportunity for disadvantaged groups in services, especially financial services. Traditionally, at the EU level antidiscrimination regulation had been developed as part of labour law. Legislation on actuarial factors differed starkly across member states, with the unisex principle mainly in place in the Scandinavian countries, France and Slovenia. The UK also had unisex tariffs for private health insurance, whereas car coverage showed sharp differences (AE, 2004). After the Amsterdam Treaty had introduced a new basis for legal action with article 13, the Commission proactively sought to extend equivalent principles to other areas, including the financial services market.

The Commission proposal $\left.\right|^{3}$ is equality enhancing in that it does away with practices of unequal treatment in terms of access to the insurance cover provided or in the level of benefits paid out. Such practices - most pronounced in motor, health and life insurance - are efficient from a purely market point of view, but they disadvantage societal groups on the basis of factors that lie beyond personal control. Against this background, in 2003 the Commission had proposed a directive implementing the principle of equal treatment between women and men regarding access to and supply of goods and services that was adopted as directive 2004/113/EC. In 2008, a more far-reaching proposal was drafted by DG EMPL. If it

\footnotetext{
${ }^{3}$ Proposal for a COUNCIL DIRECTIVE implementing the principle of equal treatment between women and men in the access to and supply of goods and services (COM(2003)657).
} 
becomes law, this proposal would extend the quest for equal treatment between the sexes in services to all persons, irrespective of religion or belief, disability, age or sexual orientation. ${ }^{4}$ Taking the effect of the directive already adopted and the pending proposal together would mean that, in principle, insurers and banks will no longer be able to use age, sex or disability in a way that discriminates against groups with these particular characteristics. This will increase costs both for insurers and for those consumers who have hitherto benefitted from the unequal market relationship. Moreover, the very fact that the Commission has intervened to explicitly extend the market to those who were previously excluded by law or in practice underlines the goal of creating more equal markets above and beyond what could be considered economically efficient.

With respect to the rationale characterizing the regulatory process in this second case, we find that while market inefficiencies were invoked in the debate, the core ambition of the drafting DG was clearly to alter the quality of this market in accordance with a political reasoning targeting greater equality. Enhancing the efficiency of markets by responding to changing environments and countering unfair practices was certainly on the agenda of the Commission, especially in view of persisting implementation difficulties (COM125, AE, 2007). However, we also note clearly voiced criticism that under the envisaged regulations the opposite outcome would be the case, because premiums would ultimately be forced upward (Minder, 2003b; Parker, 2003). Besides, the goal of increasing equality in markets was also explicitly voiced by the Commission. The proposal is described in official documents as a necessary 'signal of solidarity between women and men in European society' (Secrétariat Général, 2003:21) and as the 'result of a real moral and legal obligation' (Proposal, p.4). Commissioner Diamantopoulou stressed that there were 'political reasons for not accepting gender as an element justifying a differentiation of the treatment of individuals in the access to the supply of goods and services', as well as the signalling function of the act for European society (Secrétariat Général, 2003:21).

As suggested by our ideal-type model, this case was characterized by biased stakeholder access to favour presumably weaker parts in the regulated market relationships. In the run-up to the negotiation process in 2003, DG EMPL had very actively used and encouraged changes in interest-group organizations to create a broad front against opposition from those who wanted to keep more expensive discrimination grounds out of the discussed acts. Already prior to concrete drafting, the Commission had incentivized existing and scattered NGOs representing minorities to join forces in an umbrella organization which was not only consulted but also substantially influenced the legislative proposal. 'It was certainly strategic to involve civil society groups more than social partners [...] We saw the potential victims of discrimination as being people who were at risk of some sort of social marginalization as a result of discrimination, and they are the ones that tended not to have a voice in social partnership' (COM151). Industry, by contrast, was consulted only to provide information that would allow the Commission to follow its goal of greater market equality. To gain a better understanding of where the technical requirements of risk-based assessments for capital adequacy end and individual business interests begin, the drafting DG EMPL consulted industry early on in the drafting process for the 2008 proposal (COM42 and COM19). On the basis of the acquired knowledge, the Commission was able to argue that the question as to whether existing rules and practices had to be changed depended on the product and on whether justification could be provided 'on the basis of accurate and up-to-date data' (Commission of the European Communities, 2008: 42). The proactive and selective distribution of access for interests from different

\footnotetext{
${ }^{4}$ Proposal for a COUNCIL DIRECTIVE on implementing the principle of equal treatment between persons irrespective of religion or belief, disability, age or sexual orientation (Commission proposal $\operatorname{COM}(2008) 426)$
} 
societal segments by DG EMPL clearly contradicts the presumed neutrality of the regulator that a purely efficiency-enhancing model would imply.

Finally, with respect to the conflict structure inside the Commission, both the decision to have equal treatment legislation on financial services and the more concrete implications this would have for insurers in their actuarial practices were debated among central actors inside and outside the Commission, reflecting substantial differences in the underlying understandings of markets. Inside the Commission, DG MARKT, especially, defended the positions of industry - 'various financial sector federations' (COM42) and those member states where 'the practice of differentiating insurance costs [...] were very, very strong. UK, Ireland, but also Germany' (COM21) - by trying to carry out 'a damage limitation exercise' (COM19). DG ENTR was fundamentally opposed to having a binding act at all, and especially the broad 2008 directive, because they did not consider this a regulatory issue to be tackled at community level and feared costs for enterprises through the intervention (COM81). For these actors inside the Commission, the ideal regulatory position was for 'insurance to be [kept] completely out' (COM21). In contrast, DG EMPL, holding the pen and largely acting on normative grounds, was strongly in favour of the acts (COM21, Commissioner Diamantopoulou in Minder, 2003a), but had to overcome opposition from the critical portfolios inside the Commission as well as from opposing member states and organized interests.

The third case is the initiation of consumer credit regulation proposed by the Commission in 2002. ${ }^{5}$ Supranational regulation had existed beforehand, but it had left member states with the possibility of protecting their consumers unilaterally, so that myriad different regulations on consumer credit persisted in Europe. These barriers became increasingly relevant as consumer credit became the 'lubricant of economic life' (COM89), amounting to 7 percent of the EU-15 GDP and exhibiting an upward trend (COM119, Commission of the European Communities, 2002: 3). For the Commission's internal market Directorate-General (DG MARKT), differing national regimes hampered growth and thus needed to be removed (COM119, COM89). However, unlike most other regulations on financial services, it was not DG MARKT but the newly established consumer-policy DG SANCO, that was assigned responsibility for the regulation, and the latter DG pursued a rationale that went way beyond the facilitation of cross-border trade.

In fact, DG SANCO officials aimed at protecting the 'weak consumer' (COM89). Drafting was based on the assumption that the consumer was not able to fully grasp the implications of credit agreements and thus needed to be protected against the exploitation of that very fact by the banking or retail industry. This position was informed by observing individual cases of immensely over-indebted consumers, but also by the hype surrounding 'behavioural economics' at the time (COM89). This resulted in the redistributive 'ambition [...] to create a very comprehensive, very exhaustive consumer credit regulation which would be burdensome for industry', and DG SANCO officials transferred the most stringent national regulations they could find to the proposal (COM89), thereby increasing consumer protection rather than harmonizing at the level of the lowest common denominator.

DG SANCO's equality-enhancing approach can be highlighted by means of some of the key regulatory provisions, in which especially the principle of responsible lending was contested. The proposal fully obliged creditors to assess before the agreement whether the consumer was actually able to honour the credit obligations (Commission of the European Communities, 2002: article 9). The banking industry

\footnotetext{
${ }^{5}$ Proposal for a Directive of the European Parliament and of the Council on the harmonization of the laws, regulations and administrative provisions of the member states concerning credit for consumers COM(2003)443. This proposal was intended to repeal the existing supranational law in the area, as entailed in Directive 87/102/EEC.
} 
was shocked (ESBG, 2003: 7-9), whereas consumer associations were highly satisfied. In addition, the responsible lending principle stirred up significant internal conflict with DG MARKT (COM89; COM90). Another heatedly contested issue was the way in which the total costs of credit should be communicated to the consumer, encapsulated in the annual percentage rate (APR). Compared to the regulatory status quo, DG SANCO's proposal included a range of additional cost elements such as notary fees or even insurance premiums, meaning that creditors would have to disclose costs that went beyond their control. This rule, in particular, highlights the fact that DG SANCO was pursuing a regulatory approach involving direct and conclusive rules governing the market. The banking industry defied this as 'unworkable' (ESBG, 2003: 10), and was internally supported by DG MARKT (COM89). Finally, for credits linked to particular consumer goods, the proposed regulation would render creditors liable for defective products purchased on credit (Commission of the European Communities, 2002: article 19) - a regulatory approach borrowed from the UK Consumer Credit Act which was considered 'totally outlandish' in other EU states (COM89). The banking industry 'strongly opposed' it (ESBG, 2003: 12), again backed internally by DG MARKT (COM119). But DG SANCO stuck once more with the most stringent rule it could find amongst the member state regimes, did not try to balance competing interests and was applauded by the consumer side (EURO COOP, 2003; also BEUC, 2002: 14-5).

In sum, DG SANCO proposed a regulation that was geared towards equal protection for consumers in the European market. However, this regulation could only come about because inefficiencies had persisted in that market beforehand. These provided the basic justification for regulation, but the intentional focus on weak market participants and DG SANCO's need to demarcate its competences from those of the internal market DG resulted in a proposal that clearly aimed at redistributing rights in line with an equality-enhancing motivation. Not least, the high level of protection entailed in the regulation was driven by the political aim of protecting consumers in credit markets. Merely enhancing efficiency by removing regulatory barriers would 'deliver a bad message' politically and would be 'a very difficult position for the Commission' to be in (COM119).

The clear focus on only one societal segment was also mirrored in interest-group access. It is important to note that stakeholder meetings on the issue indicated a 'clear desire' from the consumer associations (COM111) as well as 'unanimous' opposition from the industry side. In response to this outright industry disagreement, 'further consultation was entirely avoided' by DG SANCO (ESBG, 2003: 2-3), so that 'the industry felt that it had been very much disregarded in the process' (COM119).

This intentionally skewed interest-group involvement also affected internal interaction with DG MARKT, which 'had more the ear [...] to the banking sector' (COM111). DG MARKT officials felt that banking interests were 'not being properly consulted' (COM119), which pushed the Directors-General of both DGs to the drafting table early on and resulted in a blockade of the formal inter-service consultation. As in the earlier case, these more fundamental questions were subject to exchange among Commissioners about the quality of markets, so that 'in the end it [was] a political decision' (COM89).

As predicted by the equality-enhancing model of regulation, redistribution of rights among producers and consumers was an aim rather than a constraint, detailed rules rather than self-regulation along predefined objectives were prescribed, and a neo-pluralist style of communicating with external stakeholder contacts coincided with a political bargaining process among the relevant actors within the Commission. 


\section{Conclusion: Social equality through the market?}

The case studies emphasize that regulatory decision-making in the EU can follow an equality-enhancing type of regulation and thereby take an identifiable middle ground between traditional welfare-state models and purely efficiency-focused regulation. Against this view, the social embeddedness of Europe's internal market cannot be considered as automatic as contemporary writing often seems to imply. Instead, our analysis suggests that market retrenchment at the supranational level depends on the outcome of political struggles across, and especially within the regulatory institutions of the EU. Where the regulator pursues social equality rather than solely focusing on market efficiency, the regulatory processes differ strongly in terms of their basic rationale, the chosen intervention, the type of stakeholder access and the internal conflict during rule formulation.

Initially, prevailing inefficiencies in the European Single Market were the starting point of rule-making in all three cases examined. And in the two equality-enhancing processes, the favoured societal group had to be framed as active participants in the regulated market. But rather than addressing such market failures by means of the least intrusive rule-making geared towards self-regulation, the regulators responded with encompassing and conclusive rules. Furthermore, the respective leading Commission DGs fostered and then counted on the support of consumer associations or a broad coalition of anti-discrimination NGOs and intentionally disregarded the input of other affected market stakeholders. Stakeholder access followed a neo-pluralist pattern and deviated from unbiased access in the classical conception of the regulatory state, but also from the corporatist pattern ascribed to the positive state. And, finally, the equality-enhancing processes led to strong internal opposition from other Commission DGs that would have preferred less intrusive regulatory measures.

Several implications follow for the broader question as to under which conditions market regulation in the EU pursues wider social goals. Initially, we noted that both the equal-treatment and the consumer-policy cases were driven by the agency of actors within the Commission. Equality or efficiency enhancement is always pursued by some and not by others. To answer the question as to whether we can expect Brussels to intervene only where markets fail or also where social interests demand regulation, we need a disaggregated view on Europe's central regulator. On the one hand, this refers to entrepreneurial actors in the drafting DGs. But for both cases it was also important that the Directorates-General held a decidedly social mandate due to their portfolios and could rely on treaty bases justified along equality-enhancing lines. Delineating their own competences from traditionally efficiency-oriented DGs, political entrepreneurs within the lead departments explain the push for more equality, while the available institutional mandates explain how the aim of social equality could be pursued. This finding suggests that a politicization of the selection of key personnel (Hartlapp, 2014, forthcoming) and the layout of portfolios within the Commission may significantly advance the social embeddedness of European integration.

But against this hope, it has to be noted that the apparent need to frame beneficiaries of equality-enhancing regulation as market participants still limits the scope for European re-regulation. Compared to the positive state at the national level, where social policy often targets those not able to participate in the marketplace, doubts remain as to whether the regulatory processes at the supranational level can really work to the benefit of market outsiders. Related to this, one has to keep in mind that the equality-enhancing model is also limited to the regulatory section of the overall social policy spectrum. In other words, equality enhancement in the Commission context means a redistribution of individual rights rather than resources. In a positive account, many see the fundamental rights agenda as completing the political union (Caporaso et al., 2009). Given the EU's institutional difficulties in enacting actual resource transfers, aggravated by the 
increasing heterogeneity of political preferences in the Council, individual rights provide much better opportunities for social embeddedness because they cut across traditional conflict lines. What is more, the proactive redistribution of rights can help to make the EU 'loveable' (to allude to the famous phrase by Delors that 'you cannot love a market'). However, from a more critical perspective, the shift towards regulating individual rights calls into question the traditional logic of welfare provision in the 'positive' state through social security, corporatist actors and macroeconomic stabilization. Individual rights increase the autonomy of citizens in a market setting, but they may endanger the notion of solidarity across social groups. In times when most western societies are characterized by ever-growing disparities, this might be a fatal development - even more so where the emphasis on individual rights undermines solidarity institutions that have evolved historically, for example in national labour or tax law (Scharpf, 2010; Höpner et al., 2012).

In sum, this article highlights the fact that political actors can exploit European regulation as a means to achieve broader societal goals, but are forced to take a detour via market efficiency. Put differently, while social policy in the positive state sought to decommodify individuals from the market, EU regulatory policy reflects actor interests in order to change the process and outcome of existing market transactions. In conclusion, there is scope for a social embedding of the European internal market in principle, but it is constrained by its institutional foundation, the existence of proactive agents within the Commission, a focus on market participants and the mere redistribution of rights rather than resources.

\section{References}

AE (1997a) 'EU/Insurance: BEUC and BIPAR call for European directive liberalising activities of insurance intermediaries', Agence Europe.

AE (1997b) 'EU/Insurance: Commission announces the forthcoming presentation of a directive on insurance intermediaries - BIPAR pleased', Agence Europe.

AE (2002) 'EU/Insurance: Council adopts insurance broker directive', Agence Europe.

AE (2004) '(EU) EU/Employment Council/Social: Political Agreement anticipated on Gender Equality outside Workplace - Public Debate on Social Service of General Interest', Agence Europe.

AE (2007) '(EU) EU/Social/Equality: Vladimir Spidla launches European Year for Equal Opportunities for all 2007', Agence Europe.

Akerlof, George (1970) 'The Market for "Lemons": Quality Uncertainty and the Market Mechanism', Quarterly Journal of Economics 84(3): 488-500.

BEUC (2002) Credit for consumers - BEUC position. Proposal for a Directive of the European Parliament and of the Council on the harmonisation of laws, regulations and administrative provisions of the Member States concerning credit for consumers. COM (2002) 443. Bureau Européen des Unions de Consommateurs. Brussels.

Braithwaite, John, Cary Coglianese and David Levi-Faur (2007) 'Can regulation and governance make a difference?', Regulation and Governance 1(1): 1-7.

Caporaso, James A. and Sidney Tarrow (2009) 'Polanyi in Brussels: Supranational Institutions and the Transnational Embedding of Markets', International Organization 63(04): 593-620.

Cioffi, John W. (2009) 'Adversarialism versus legalism: Juridification and litigation in corporate governance reform', Regulation and Governance 3(3): 235-58. 
Coen, David and Mark Thatcher (2008) 'Network Governance and Multi-level Delegation: European Networks of Regulatory Agencies', Journal of Public Policy 28(01): 49-71.

Commission of the European Communities (2002) Proposal for a Directive of the European Parliament and of the Council on the harmonisation of the laws, regulations and administrative provisions of the Member States concerning credit for consumers. COM(2002)443. Brussels.

Commission of the European Communities (2008) Commission Staff Working Document. Proposal for a Council Directive on implementing the principle on equal treatment between persons irrespective of religion or belief, disability, age or sexual orientation - Impact Assessment. SEC(2008) 2180.

Dassesse, Marc (1997) 'Comments on the European Commission Green Paper 'Financial service: Meeting consumers' expectations", Journal of Financial Regualtion and Compliance 5(2): 107-14.

Dunleavy, Patrick and Brendan O'Leary (1987) Theories of the State. Houndmills, Basingstoke: Palgrave Macmillan.

ESBG (2003) On the Commission's Proposal for a Directive of the European Parliament and of the Council on the harmonisation of laws, regulations and administrative provisions of the Member States concerning credit for consumers COM (2002) 443 Final, European Savings Banks Group. Brussels.

EURO COOP (2003) EuroCoop Position Paper On The Revision of the Consumer

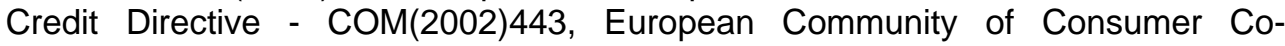
operatives. Brussels.

Falkner, Gerda, Oliver Treib, Miriam Hartlapp and Simone Leiber (2005) Complying with Europe. EU Minimum Harmonisation and Soft Law in the Member States. Cambridge: Cambridge University Press.

Grande, Edgar (2011) 'De-Regulation and Re-Regulation of Public Utilities: The New Regulatory State in the European System of Multi-Level Governance', in Lutz Leisering (ed.) The New Regulatory State. Regulating Pensions in Germany and the UK. Basingstoke: Palgrave Macmillan, pp. 57-79.

Hartlapp, Miriam (2014, forthcoming) 'Politicization of the European Commission: When, how and with what impact?', in Michael W. Bauer and Jarle Trondal (eds) The Administrative System of the European Union. Basingstoke: Palgrave.

Hartlapp, Miriam, Julia Metz and Christian Rauh (2013) 'Linking Agenda Setting to Coordination Structures: Bureaucratic Politics inside the European Commission', Journal of European Integration 53(4): 425-441.

Hervey, Tamara and Louise Trubek (2007) 'Freedom to provide health care services in the EU: an opportunity for "hybrid government", Columbia Journal of European Law 13: 623-47.

Höpner, Martin and Armin Schäfer (2012) 'Embeddedness and Regional Integration.Waiting for Polanyi in a Hayekian Setting', International Organization 66(3): 429-55

Knill, Christoph and Andrea Lenschow (2003) 'Modes of Regulation in the Governance of the European Union: Towards a Comprehensive Evaluation', European Integration Online Papers (EloP) 7(1).

Leibfried, Stephan (2010) 'Social Policy. Left to the Judges and the Markets?', in Helen Wallace, Mark Pollack and Alasdair R. Young (eds) Policy-Making in the European Union. Oxford: Oxford University Press, pp. 253-81.

Leisering, Lutz (2011a) 'Transformations of the State: Comparing the New Regulatory State to the Post-war Provider State', in Lutz Leisering (ed.) The New 
Regulatory State. Regulating Pensions in Germany and the UK. Houndmills, Basingstoke: Palgrave Macmillan, pp. 254-74

Leisering, Lutz (2011b) 'Transformations of the State: Comparing the New Regulatory State to the Post-war Provider State', in Lutz Leisering (ed.) The New Regulatory State. Regulating Pensions in Germany and the UK Palgrave Macmillan.

Levi-Faur, David (2012) 'States Making \& Market Building for the Global South: The Developmental State vs. The Regulatory State?', Jerusalem Papers in Regulation and Governance. Working Paper No. 44 (July 2012).

Lowi, Theodore J. (1964) 'Review: American Business, Public Policy, CaseStudies, and Political Theory', World Politics 16(4): 677-715.

Mabbett, Deborah (2009) 'Supplementary Pensions between Social Policy and Social Regulation', West European Politics 32(4): 774 - 91.

Majone, Giandomenico (1993) 'The European Community Between Social Policy and Social Regulation', Journal of Common Market Studies 31(2): 153-70.

Majone, Giandomenico (1996) Regulating Europe. London: Routledge.

Majone, Giandomenico (1997) 'From the Positive to the Regulatory State: Causes and Consequences of Changes in the Mode of Governance', Journal of Public Policy 17(02): 139-67.

McVea, Harry (2005) 'Financial Services Regulation under the Financial Services Authority: A reassertion of the market failure thesis?', Cambridge Law Journal 64(02): 413-48.

Minder, Raphael (2003a) 'Gender banned from use in setting premiums', Financial Times.

Minder, Raphael (2003b) 'Insurers to fight Brussels over bar on sex discrimination', Financial Times.

Parker, George (2003) 'EU targets sex bias in media and insurance: Ambitious move to enshrine 'respect for human dignity' could force up premiums', Financial Times.

Posner, Elliot and Nicolas Véron (2010) 'The EU and financial regulation: power without purpose?', Journal of European Public Policy 17(3): 400-15.

Princen, Sebastiaan (2009) Agenda-Setting in the European Union. Houndmills: Palgrave.

Prosser, Tony (2006) 'Regulation and Social Solidarity', Journal of Law and Society 33(3): 364-87.

Quaglia, Lucia (2010) 'Completing the single market in financial services: the politics of competing advocacy coalitions', Journal of European Public Policy 17(7): 1007 - 23.

Ramsay, Ian (1995) 'Consumer Credit Law, Distributive Justice and the Welfare State', Oxford Journal of Legal Studies 15(2): 177-97.

Reagan, Michael (1987) Regulation: The Politics of Policy. Boston: Little, Brown and Company.

Sbragia, Alberta M. (2000) 'Governance, the State, and the Market: What Is Going On?', Governance 13(2): 243-50.

Sbragia, Alberta and Francesco Stolfi (2008) 'Key Policies', in Elizabeth Bomberg, John Peterson and Alexander Stubb (eds) The European Union: How Does it Work. Oxford: Oxford University Press?, pp. 116-37. 
Scharpf, Fritz W. (1999) Governing in Europe: Effective and democratic? Oxford: Oxford University Press.

Scharpf, Fritz W. (2010) 'The asymmetry of European integration, or why the EU cannot be a 'social market economy", Socio-Economic Review 8(2): 211-50.

Schmitter, Philippe C. and Gerhard Lehmbruch (eds) (1979) Trends Towards Corporatist Intermediation. London: Sage.

Secrétariat Général (2003) MINUTES of the 1633rd meeting of the Commission held in Brussels (Breydel) on Wednesday 5 November 2003 (morning), PV(2003)1633 final. Brussels.

Stiglitz, Joseph E. (1986) Economics of the Public Sector. New York: Norton.

Truman, David B. (1951) The Governmental Process: Political Interests and Public Opinion. New York: Alfred A. Knopf.

Tsebelis, George and Geoffrey Garrett (2000) 'Legislative Politics in the European Union', European Union Politics 1(1): 9-36.

Vogel, David (2003) 'The Hare and the Tortoise Revisited: The New Politics of Consumer and Environmental Regulation in Europe', British Journal of Political Science 33(04): 557-80.

Weingast, Barry R. (1995) 'The Economic Role of Political Institutions: MarketPreserving Federalism and Economic Development', Journal of Law, Economics, and Organization 11(1): 1-31.

Windholz, Eric and Graeme A. Hodge (2013) 'Conceptualising Social and Economic Regulation: Implications for Modern Regulators and Regulatory Activity', Jerusalem Papers in Regulation \& Governance. Working Paper No. 49 (Feburary 2013). 